\section{A. ARS BILDUMA \\ ISSN 1989-9262 \\ UPV/EHU Press}

ARSBILDUMA (CC BY-NC-ND 4.0)

https://doi.org/10.1387/ars-bilduma.21884 BIBLID [(2021), 11; 15-31]

Recibido: 23/03/2020 Aceptado: 27/07/2020

\section{GUILLERMO JUBERÍAS GRACIA}

Universidad de Zaragoza

Facultad de Filososfía y Letras

Departamento de Historia del Arte

C/ Corona de Aragón, 42

50009, Zaragoza (Zaragoza)

guillermojuberias@unizar.es

https://orcid.org/0000-0003-0098-5287

Miembro del grupo de investigación consolidado Observatorio Aragonés de Arte en la Esfera Pública, subvencionado con fondos FEDER y Gobierno de Aragón.

Este artículo es fruto de una estancia de investigación en el HiCSA (Centre de Recherche en Histoire Culturelle et Sociale de l'Art) de la Université de Paris 1

- Panthéon Sorbonne, subvencionada por el Ministerio de Educación y Formación Profesional.

\title{
LOS DECORADOS DE GOYESCAS EN SU ESTRENO PARISINO (1919). NUEVOS DATOS SOBRE EL TRABAJO DE ZULOAGA Y DETHOMAS
}

\author{
GOYESCAS' SETS FOR ITS PARISIAN PREMIERE (1919). NEW DATA ON THE \\ WORK OF ZULOAGA AND DETHOMAS
}

LES DÉCORS DE GOYESCAS POUR SA PREMIERE PARISIENNE (1919). DES NOUVELLES DONNÉES SUR LE TRAVAIL DE ZULOAGA ET DETHOMAS

RESUMEN

Ignacio Zuloaga y Maxime Dethomas elaboraron los decorados de la ópera Goyescas de Enrique Granados para su estreno parisino en 1919. Arrojamos nuevos datos sobre su trabajo gracias al estudio de la correspondencia conservada en los Archives du Théatre National de l'Opéra, al hallazgo de dos maquetas inéditas del primer y tercer cuadro de Goyescas y de abundante material fotográfico. A través del presente artículo se estudian estas obras en su contexto de producción, analizando las fuentes utilizadas por sus creadores.

\section{PALABRAS CLAVE}

Goyescas; Zuloaga; Dethomas; Granados; escenografía; ópera; diseños de vestuario.
ABSTRACT

Ignacio Zuloaga and Maxime Dethomas produced the sets of Enrique Granados opera Goyescas for its Parisian premiere in 1919. We present new data about their work thanks to the study of the letters preserved in the Archives du Théatre National de l'Opéra, the discovery of two unpublished models of the first and third Goyescas act and a rich photographic material. Through this article we study these works in their production context, analyzing the sources used by their creators.

\section{KEYWORDS}

Goyescas; Zuloaga; Dethomas; Granados; scenography; opera; dress designs.
RÉSUMÉ

Ignacio Zuloaga et Maxime Dethomas ont créé les décors de lopéra Goyescas d'Enrique Granados pour sa première à Paris en 1919. Des nouvelles données sur son travail sont diffusées grâce à l'étude de la correspondance conservée aux Archives du Théatre National de l'Opéra, à la découverte de deux maquettes inédites des premier et troisième tableaux de Goyescas et d'une riche documentation photographique. Ces oeuvres sont étudiées dans le contexte de leur production, en analysant les sources utilisées par leurs créateurs.

\section{MOTS-CLÉS}

Goyescas; Zuloaga; Dethomas; Granados; scénographie; opéra; dessins de costumes. 


\section{INTRODUCCIÓN}

La manera en que España proyectaba su propia imagen en el extranjero fue una de las mayores preocupaciones de los políticos, artistas e intelectuales de finales del siglo XIX y comienzos del XX. Al respecto, el Desastre del 98 marcó un punto de inflexión en este proceso, obligando a los creadores a formular nuevas visiones que demostrasen que, frente a la crisis política y a la pérdida de las últimas colonias, la cultura nacional seguía viva. Un territorio todavía poco transitado es el del estudio de las escenografías y decorados teatrales de obras producidas en esta época. Goyescas, la ópera de Enrique Granados (1867-1916), ofrece al respecto un ejemplo paradigmático de colaboración entre el compositor ilerdense y artistas como el pintor Ignacio Zuloaga (1870-1945) y su cuñado, el diseñador Maxime Dethomas (1867-1929), para el estreno parisino de la ópera en 1919, con Granados ya fallecido. A través del presente estudio se analizan pormenorizadamente sus decorados, que no dejan de ser reflejo de las inquietudes y preocupaciones de la cultura española de comienzos del siglo XX. Por una parte, veremos cómo a través de los diseños ideados por Zuloaga y Dethomas, se intenta transmitir una visión de España alejada de la perspectiva del romanticismo francés. Este se había interesado fundamentalmente por el arte hispanomusulmán, circunstancia aprovechada por las instituciones como puede comprobarse en los pabellones españoles presentados a las exposiciones internacionales del siglo XIX ${ }^{1}$. La ópera de Granados identifica al pueblo español con las clases populares de la España de Carlos IV, recuperando el universo visual de la pintura de Goya y ofreciendo una nueva interpretación de la música culta española. Al respecto, los decorados de Zuloaga y Dethomas se alejan del tipismo andalucista de las escenografías de Carmen ${ }^{2}$ y del casticismo del estreno de Goyescas en Nueva York en 1916. Frente a ello, los artistas que colaboraron en el debut parisino de Goyescas buscaron una interpretación novedosa de la obra del pintor de Fuendetodos. A través del presente estudio mostramos las fuentes que utilizaron Zuloaga y Dethomas para sus creaciones, relacionándolas con el contexto cultural en el que fueron producidas.

1 Sobre esta cuestión de la imagen de España en las exposiciones parisinas de la segunda mitad del siglo XIX: SAZATORNIL RUIZ L. Y LASHERAS PEÑA, A. B. "París y la españolada Casticismo y estere

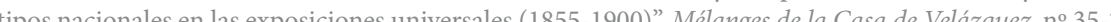
2005, pp. 265-290

2 Estos fueron difundidos por Evan Baker en: BAKER, E.: "The Scene Designs for the First Performance of Bizet's Carmen", 19th Century Music, vol. 13, n 3, 1990, pp. 230-242
2. PARÍS Y LA FASCINACIÓN POR LA MÚSICA ESPAÑOLA. LA CORRESPONDENCIA ENTRE ENRIQUE GRANADOS Y JACQUE ROUCHÉ

"Queda entendido que Goyescas no podrá representarse en ningún teatro extranjero antes de que el estreno tenga lugar en París"3. Con estas palabras escritas en junio de 1914, Jacques Rouché (1862-1957), director de la Ópera de París, manifestaba su interés en que Goyescas, la ópera del maestro Enrique Granados, fuese estrenada en la capital francesa. Sin embargo, tres meses después, el Palais Garnier cerraba sus puertas temporalmente a consecuencia del estallido de la Primera Guerra Mundial, suspendiendo su actividad artística y aplazando indefinidamente la puesta en escena de numerosos proyectos musicales y dramáticos.

Goyescas había entusiasmado al público francés incluso antes de que Granados idease su célebre ópera. Al compositor debió de interesarle la difusión de esta obra en Francia, pues poco después del estreno de su suite para piano en la Sala Pleyel de Barcelona en marzo de 1911, dio un concierto en París a comienzos de abril en el que pudieron escucharse algunas de sus piezas inspiradas en la época de Carlos IV. Fueron bien acogidas por el público parisino, afirmándose en la prensa del momento que "merecían una mención especial por su originalidad y su inspiración”. Desde la célebre revista Comoedia, el crítico musical Michel-Dimitri Calvocoressi se lamentaba de conocer todavía tan poco el recorrido del remarcable compositor de estas suites ${ }^{4}$. Durante el verano de ese mismo año volvió a representar su pieza, en este caso en la Société Nationale de Musique ${ }^{5}$. De esta manera Granados generó en Francia una expectación por este género de música española inspirada en la época de Goya.

Para comprender el triunfo que Goyescas y sus decorados alcanzaron posteriormente en 1919, es necesario contextualizar la afición parisina a las óperas de temática española y la difusión de la que gozaba la figura de Goya en Francia. El compositor ilerdense era el principal interesado en que su obra fuese representada en el Palais Garnier, por la existencia en la ciudad de un público fiel a la "españolada"6 tras los estrenos de obras

3 Archives du Théâtre National de l'Opéra [ATNO]. AJ/13/1205. Carta de Jacques Rouché a Enrique Granados. París: 22-06-1914

4 CALVOCORESSI, M. D "Aux concerts" Comedin Illustré: journal artistique bi-mensuel. Paŕs, 15 de abril de 1911, p. 449

CALVOCORESSI, M. D.: ibid., p. 681.

La definición de este término en francés (espagnolade), alberga aun hoy en día un sentido peyorativo, 
escritas por compositores franceses pero inspiradas en España. La fascinación que los viajeros románticos franceses manifestaron por la Península Ibérica acabó saltando a los escenarios, llevando a un público amplísimo este gusto por lo español, idealizado y sometido a las deformaciones de la óptica romántica, transmitiendo una imagen de España poco contrastada y reduccionista en la medida en que andalucismo y flamenquismo fueron interpretados como sinónimo de lo español, olvidando otras identidades regionales también poseedoras de sus propios referentes visuales y musicales. A la luz de esta moda se estrenaron Carmen de Bizet (1875), España de Chabrier (1883) o la composición de Iberia de Debussy (1905-1912) ${ }^{7}$. Los decorados del estreno parisino de Carmen, ejecutados por Émile Bertin y conservados al igual que los de Goyescas en la Bibliothèque-Musée de l'Opéra, ponen de manifiesto esa visión estereotipada (fig. 1$)^{8}$.

Los creadores españoles aprovecharon este interés que su país suscitaba en los escenarios de la capital francesa para intentar, en la medida de lo posible, dar salida a sus producciones. La música española se popularizó en el París de finales del siglo XIX, donde cobraron fama arriesgadas iniciativas como la de Matías Miquel, promotor de la Sociedad Española de Cuartetos -que entre 1887 y 1889 difundió repertorios en los que se daba a conocer la "música culta española" - y de las populares Soirées Espagnoles del Teatro de Vaudeville, organizadas con la colaboración de la cantante Elena Sanz? . Ese interés en la difusión de la música culta fue creciendo a comienzos del siglo XX, obligando a los músicos, literatos

alusivo a su falta de exactitud en la representación de lo español: "obra artística o literaria que presenta a España en una época indeterminada, alejada de su realidad profunda". Definición proporcionada po el Centre National de Ressources Textuelles et Lexicales: https://www.cnrtl.fr/definition/espagnolade (fecha de consulta: 23-01-2020). Desde comienzos de la Restauración hubo intelectuales españoles

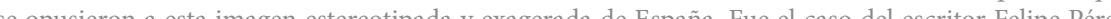
y González, el autor de la zarzuela La Gran hia. En sus articulos periodisticos denunció el uso que los franceses hacían de la españolada, sin embargo, en su propia literatura explotó el tópico españo También el dramaturgo Carlos Luis de Cuenca rechazó la visión de una España de guitarra y navaja comienzos del siglo XX. Para profundizar en esta cuestión: TRANCART, V:: "Denuncia de la españolada", en TRANCART, V.: Visiones desafinadas. Prácticas y representaciones de la guitarra en Madrid y en Andalucía (1883-1922). Zaragoza, Prensas de la Universidad de Zaragoza, 2019, pp. 365-367.

VILA, M. C.: Rêve d'Espagne. Musique espagnole en France. París, Fayard, 2018, p.

8 Bibliothèque-Musée de l'Opéra [BMO]. Esquisse de décor de l'acte II/Émile Bertin. Ref. FRBNF39750952.

9 BERGADȦ ARMENGOL, M.: "Musiciens espagnols à Paris entre 1820 et 1868 ", en JAMBOU, L. (coord.), La musique entre France et Espagne. Interactions stylistiques 1870-1939. París, Presses de l'Université de Paris-Sorbonne, 1998, pp. 109-128

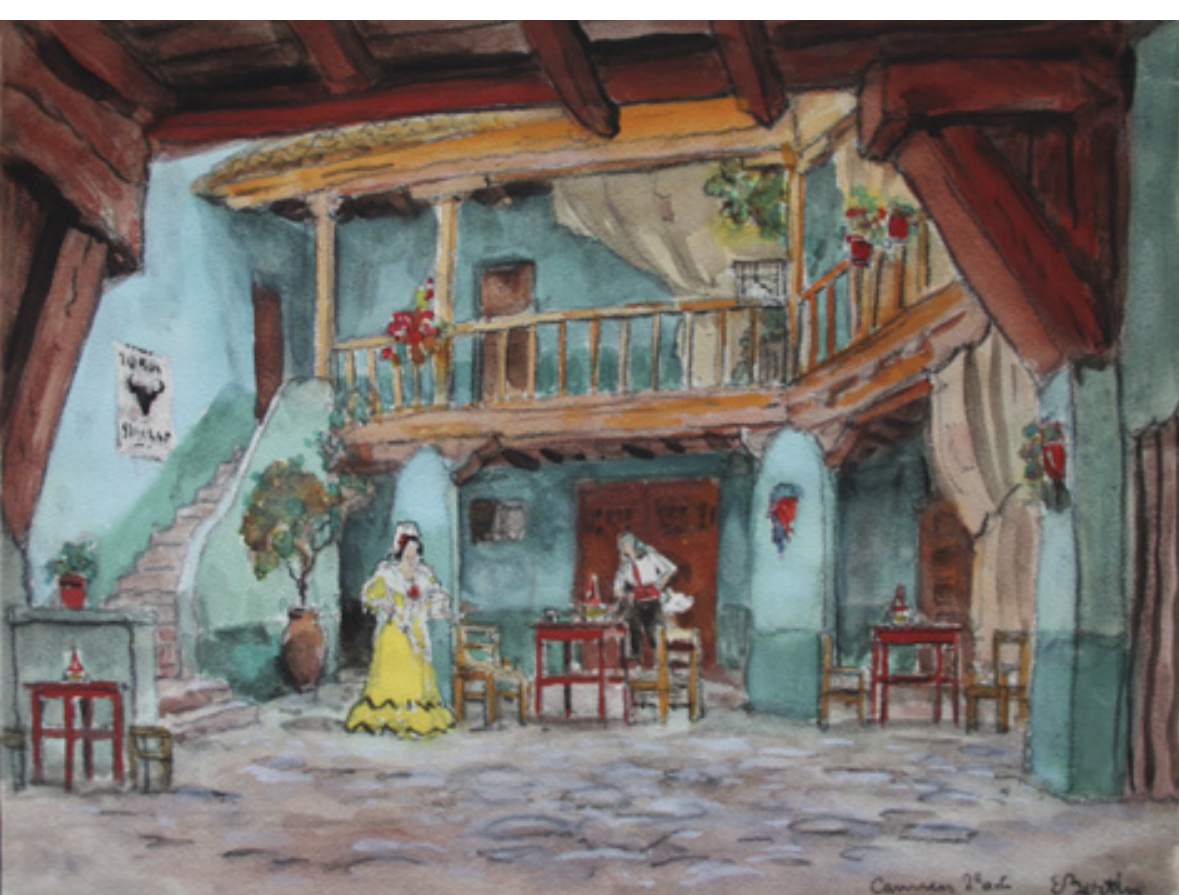

Fig. 1: Decorado para el segundo acto de Carmen, Émile Bertin, 1875. Bibliothèque-Musée de l’Opéra, Bibliothèque Nationale de France, París

y creadores de decorados a repensar sus producciones, dando lugar a productos de una inspiración nacional más depurada y fiel a la realidad. Ese mismo propósito es el que apreciamos en Goyescas, tanto en su parte musical como en su puesta en escena.

Las temáticas españolas triunfaban en Francia, no sólo en los espectáculos sino también en otras manifestaciones artísticas como la pintura ${ }^{10}$. Tras el temprano fallecimiento de Fortuny en 1874, oleadas de creadores españoles se asentaron en la capital francesa,

10 BERGADÀ ARMENGOL, M.: "Añoranza y proyección musical de España en el París de finales del siglo XIX", Cuadernos de música iberoamericana, vol. 5, 2003, pp. 31-32. 
tratando de emular el éxito del maestro de Reus. Cultivaron asuntos castizos, explotando un madrileñismo y un andalucismo muy populares entre el público francés ${ }^{11}$. Sin embargo, el tipismo llevado al exceso condujo a un cierto agotamiento de la pintura de género española y de los espectáculos más castizos. Frente a ello, Goyescas de Granados aportaba una revisión de ese imaginario bien conocido, renovado en los decorados de Ignacio Zuloaga y Maxime Dethomas.

Además, el universo visual goyesco no debió resultar del todo ajeno al público parisino, pues, a comienzos del siglo XX, el maestro aragonés era bien conocido en Francia. Abundantes pinturas, grabados y dibujos de Goya formaban parte de colecciones públicas y privadas francesas. Entre las primeras cabe destacar los goyas expuestos en los museos del Louvre, Lille, Castres, Besançon, Agen o Bayona ${ }^{12}$. Asimismo, hubo personajes en Francia que coleccionaron obras del maestro aragonés, tal fue el caso del modisto Jacques Doucet, quien mostraba dos supuestos goyas, retratos del duque y la duquesa de Alba en su hôtel de la parisina Rue Spotini ${ }^{13}$. Relacionado con este coleccionismo privado estuvieron las ventas de obras de Goya en subastas parisinas a finales del siglo XIX, en las que además se dio a conocer la obra del artista gracias a la exposición que por norma general antecedía a cualquier venta pública ${ }^{14}$.

En este contexto, Granados suponía que Goyescas gozaría de gran éxito en los escenarios del Palais Garnier, gracias también al asesoramiento artístico del pintor Ignacio Zuloaga, quien para entonces ya había realizado colaboraciones con compositores para óperas y espectáculos de temática casticista ${ }^{15}$. Sin embargo, los meses iban pasando, la contienda no terminaba y su ópera no tenía siquiera una fecha de estreno. Mientras tanto fue recibiendo

11 REYERO HERMOSILLA, C.: "Soy de España. El casticismo de los pintores españoles en el Salón de París durante el II Imperio", Cuadernos de Arte i Iconografía, vol. IV, 8, 1991, pp. 314-322.

12 LORENTE LORENTE, J. P.: "De Goya a Zuloaga: Pinturas de los artistas decimonónicos españoles en lo museos de Francia”, en CABAÑAS BRAVO, M. (coord.): El arte español fuera de España. Madrid, CSIC Instituto de Historia, 2003, pp. 331-342.

13 Conocemos el aspecto del salón en el que se encontraban estas obras gracias a una ilustración de Adrien Karbowsky. Para más información: ANDRE-DECONCHAT, S.: "Loeuvre de Goya dans les collections de Jacques Doucet”, en VV. AA., Goya graveur. París, Petit Palais, 2008, pp. 161-169.

14 Al respecto un evento importante que no ha suscitado hasta subasta 1877 de 105 dibjos de Fracico de Goya en el Hôtel Drout, acotecimieno a la difusión del pintor de Fuendetodos. Archives de Paris [AP]. Archives judiciaires, commissaires-priseurs: Delestre. Signatura: D60E3 32.

15 Ya había colaborado con el ilustrador Xavier Gossé para la puesta en escena de la ópera de Manuel de propuestas para estrenarla en Estados Unidos, la más atractiva la del Metropolitan Opera House de Nueva York. Por su parte, Jacques Rouché explicó al compositor la necesidad de que el pase de París fuese el primero, pues de lo contrario la ópera no se consideraría nueva y no podría ser sufragada por el Estado ${ }^{16}$. El músico catalán aceptó estos términos a condición de que su obra fuese estrenada en la primera sesión de la Ópera en su reapertura ${ }^{17}$. Sin embargo, el compositor comenzó a tener problemas económicos consecuencia de la parálisis de su actividad, por lo que, a finales de mayo de 1915, volvió a escribir a Rouché transmitiéndole su preocupación por la guerra, en la que el armisticio quedaba todavía muy lejano. Por este motivo, acabó pidiendo al director de la Ópera que cancelase la exclusividad para poder estrenarla en Nueva York ${ }^{18}$. En mitad de esta negociación, el libretista de la ópera, Fernando Periquet (1873-1940), escribió a Rouché anunciándole que estrenarían Goyescas en Nueva York, pero reservando el primer pase europeo al Palais Garnier ${ }^{19}$.

La ópera debutó en el Metropolitan Opera House el 28 de enero de 1916, con una buenísima recepción del público y la crítica. Goyescas avivó en Nueva York una moda por lo español similar a la vivida en la capital francesa durante el siglo anterior, circunstancia que se había visto reforzada por la apertura en 1908 de la Hispanic Society of America, donde Granados depositó una copia original de la partitura y dos facsímiles, uno de Los majos enamorados y otro de la estampa número 5 de Los Caprichos de Goya ${ }^{20}$. Los decorados de estreno neoyorkino fueron obra del escenógrafo italiano Antonio Rovescalli (1864-1936), contando con el asesoramiento de Periquet para los fondos de escena y los trajes. Se conoce bien el decorado del segundo cuadro, gracias a las imágenes publicadas en la prensa, lo que

Falla Pepita Jiménez, estrenada en 1896 en el Gran Teatro del Liceo de Barcelona. También había recibido el encargo del director de la Ópera de Berlín en 1905 de ejecutar la escenografía de Carmen. Unos años más tarde, en 1915, elabó que Granados. Sobre la colaboración de Zuloaga con estos compositores y el papel desempeñado por la bailarinas en los procesos creativos: MURGA CASTRO, ., Música y pintura encarnadas: las bailarina de Falla y de Zuloaga", en PÉREZ-FAJARDO, C. A. (coord.): Ignacio Zuloaga, Manuel de Falla. Historia de una amistad. Madrid, Centrocentro Cibeles, 2015, pp. 91-119.

16 ATNO. AJ/13/1205. Carta de Jacques Rouché a Enrique Granados. París: 22-03-2015.

17 ATNO. AJ/12/1205. Carta de Enrique Granados a Jacques Rouché. Barcelona: 14-05-1915.

18 ATNO. AJ/12/1205. Carta de Enrique Granados a Jacques Rouché. Barcelona: 28-05-1915

19 ATNO AJ/12/1205. Carta de Fert

20 Para más información sobre el estreno neoyorquino de Goyescas y los decorados ejecutados por Antonio Rovescalli: JUBERÍAS GRACIA, G.: "Goyescas (1915): pintores y escenógrafos al servicio de la ópera de Granados", en CALVO RUATA, J. I.: Goya en la Literatura, la Música y las Creaciones Audiovisuales. Zaragoza, Institución Fernando el Católico, p. 261. Este capítulo constituye una breve introducción al 
demuestra cómo Rovescalli fue bastante conservador, construyendo un patio interior lleno de personajes a la manera de los cuadritos de costumbres que tanta fortuna tuvieron en la pintura del siglo XIX. La modernidad de los decorados ideados por Zuloaga y Dethomas para el estreno parisino en 1919 evidenció una comprensión de lo goyesco más profunda y original, tal y como demuestran las maquetas y los figurines analizados en este artículo.

Como es sabido, Granados no llegó a ver el debut de su ópera en París, pues en marzo de 1916 durante su regreso de Norteamérica, el vapor en el que viajaba, el Sussex, fue torpedeado por un submarino alemán al atravesar el Canal de la Mancha.

\section{LA RESPUESTA ESTÁ EN GOYA: EL MAESTRO ARAgONÉS Y LA} CONSTRUCCIÓN DE UNA IDENTIDAD VISUAL ESPAÑOLA

Para comprender el contexto cultural en el que fueron ideados los decorados de Goyescas es necesario apuntar cómo Francisco de Goya fue un importante referente para la intelectualidad española de finales del siglo XIX. Esta época, frente a la crisis del Estado liberal decimonónico y a la inestabilidad política de las últimas décadas de la centuria, el nacionalismo cultural buscó sus referentes creativos en el arte de los maestros de la tradición pictórica española: primero Velázquez y Murillo durante las dos primeras décadas de la Restauración, y más adelante Goya y el Greco, sobre todo tras el Desastre de $98^{21}$. Este fenómeno culminó en lo que Francisco Calvo Serraller denominó "la invención del arte español"22.

En la segunda mitad del siglo XIX, el maestro aragonés vivió un proceso de reivindicación y puesta en valor desde las instituciones estatales, pasando a ser un instrumento muy eficaz para el asentamiento del nacionalismo cultural español ${ }^{23}$. Prueba de ello fue la inauguración

asunto de los decorados de esta obra y fue escrito antes del descubrimiento de las maquetas de Zuloaga y Dethomas y de las fotografías conservadas en el archivo de la Bibliothèque-Musée de l'Opéra de París. Tampoco se incluyen referencias a la repercusión de la ópera y sus decorados en la capital francesa. A través del presente estudio difundimos todas estas novedades, trazando un panorama completo para el estudio de su puesta en escena.

21 PORTÚS PÉREZ, J.: El concepto de pintura española. Madrid, Verbum, 2012, p. 150

22 CALVO SERRALLER, F.: La invención del arte español. Barcelona, Galaxia Gutemberg, 2013.

23 VEGA GONZÁLEZ, J. y VIDAL RIVAS, J.: "El devenir de la Historia del Arte, sus prácticas y sus con- en el Museo del Prado en 1875 de la "Sala de Goya", la primera sala monográfica dedicada un artista, destinada a la exposición de sus cartones para tapices, tan presentes en los decorados aquí investigados. En 1898 fue creada otra sala de Goya, en la que ya se incluyeron retratos de corte y las Pinturas Negras ${ }^{24}$. La reivindicación del maestro aragonés alcanzó su punto culminante en 1900 con la exposición monográfica organizada por el Ministerio de Instrucción Pública y Bellas Artes y con el traslado de sus restos al cementerio de San Isidro y su entierro definitivo en San Antonio de la Florida en $1919^{25}$.

Estas políticas institucionales tuvieron su eco en las iniciativas particulares. Así, en 1906 Blasco Ibáñez publicaba una novela titulada La maja de Goya y al año siguiente Blanca de los Ríos daba a conocer su Madrid goyesco. Este renovado majismo también se reflejó en las fiestas y bailes privados, en los que se puso de moda reproducir las pinturas del maestro aragonés conformando tableaux vivants ${ }^{26}$. Estos eventos, a caballo entre el ocio burgués y el homenaje artístico, apenas han suscitado la atención de los investigadores. Sin embargo consideramos que la moda de los "cuadros vivos" goyescos mantuvo una relación muy estrecha con la celebración de espectáculos de las mismas temáticas, al estar en ocasiones supervisados por pintores de renombre como Horacio Lengo Martínez o José Moreno Carbonero. Estos acontecimientos unían pintura, vestuario, decoración y, ocasionalmente, eran celebrados en lugares como el Teatro Real de Madrid ${ }^{27}$. Por lo tanto, las fronteras entre diversas manifestaciones artísticas eran cada vez menos pronunciadas.

secuencias: el caso de Francisco de Goya", en ARCINIEGA GARCÍA, L.: Memoria y significado: uso recepción de los vestigios del pasado. Valencia, Universitat de València, 2013, pp. 341-422.

24 JUBERÍAS GRACIA, G., "Ideología y poder en los discursos museográficos: la creación de «salas de Goya» en los museos españoles (1875-1915)”, Potestas, 14, 2019, pp. 143-163.

25 VEGA GONZÁLEZ I (ed.): Goya 1900 Catálogo ilustrado y estudio de la exposición en el Ministerio de Instrucción Pública y Bellas Artes. Madrid, Ministerio de Cultura, 2002

26 Gran atención mediática consiguió la fiesta celebrada en 1884 en el palacio de los duques de Medinacel en Madrid. En ella se organizaron cuadros vivos inspirados en las pinturas de Francisco de Goya. Así lo narraba la crónica del diario El Día: "Entre estos dos grupos, allá en el fondo, copiando un tapiz de Goya manolas y chisperos jugaban a la gallina ciega". La familia Madrazo acudió al evento, quedando como testimonio un boceto en el que Federico de Madrazo retrató a su nieta María Luisa vestida de maja goyesca: J.G.A: "Madrid", El Día, Madrid, 24 de febrero de 1884, p. 4

27 Allí se organizó en 1910 un baile de disfraces de temática goyesca para el cual se decoró el foyer del teatro con tapices de Goya prestados por la Case Real y por coleccionistas particulares. Del mismo modo hos

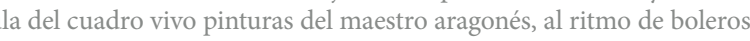
tonadillas y fandangos del siglo XVIII: "Las fiestas del Carnaval. Baile goyesco", La Correspondencia de España, Madrid, 12 de enero de 1910, p. 5 
Granados y Zuloaga también se vieron envueltos en este fervor goyesco. Al primero le interesó mucho el majismo de finales del siglo XVIII, especialmente el de Goya y Ramón de la Cruz. Del segundo copió los títulos de algunos de sus sainetes como sucedió con $E l$ fandango del candil, uno de los cuadros de Goyescas ${ }^{28}$. Este historicismo ya se apreció en 1914 en su serie de composiciones para voz y para piano Doce tonadillas en estilo antiguo. Las historias reflejan la cotidianeidad y los enredos amorosos del Madrid de finales del siglo XVIII, su fuente de inspiración, llegando a titular una tonadilla como La maja de Goya.

Este interés por el majismo también se dio en la faceta de dibujante de Granados, un perfil muy poco conocido. La Pierpoint Morgan Library de Nueva York conserva un cuaderno del compositor en el que incluyó anotaciones musicales y dibujos realizados por él mismo sobre las Tonadillas ${ }^{29}$. Dio como título al cuaderno: Apuntes para mis obras ${ }^{30}$ Sobresalen los dibujos que acompañan a la tonadilla La maja dolorosa $n^{\circ} 2$, en los que el compositor representó una muchacha ataviada con mantilla negra y peineta. El atuendo y la técnica dibujística remiten directamente a modelos goyescos, más en concreto, evocan representaciones de los álbumes de dibujos de Goya, sobre todo del Álbum B o de Madrid. En esa misma página incluyó una imagen de una maja en el balcón, también ataviada con mantilla negra, peineta y, en este caso, abanico. Otra de las ilustraciones más goyescas entre las creadas por Granados es una representación de La maja de paseo. La imagen que parece haber inspirado directamente este dibujo de Granados es precisamente la estampa número 5 de Los Caprichos. Completa el conjunto un brillante dibujo coloreado que muestra el Coloquio en la reja.

La evocación de ese universo casticista responde al propósito de Granados de crear composiciones tradicionales, pero a la vez novedosas: "hecho en modo popular, sí, pero originales" ${ }^{\prime 1}$. Al igual que hizo Zuloaga en sus decorados, no copió, sino que reinterpretó las imágenes goyescas.

28 CLARK, W. A.: Enrique Granados: Poet of the Piano. Nueva York, Oxford University Press, 2006, pp. $115-120$.

Algunos de los dibujos fueron publicados por Walter Aaron Clark en Ibid., pp. 66 y 67

30 The Morgan Library \& Museum. ID de registro: 114565.

31 RHODES DRAAYER, S.: Art Song Composers of Spain: An Encyclopedia. Lanham, Scarecrow Press, 2009, p. 272.
En el caso de Zuloaga, su pasión por Goya ha sido bien estudiada ${ }^{32}$. El artista viajó por primera vez a la capital francesa en 1889 y ya en los retratos de su etapa parisina laten pulsiones goyescas que van de lo superficial - el detalle casticista de las mantillas, los abanicos y demás componentes del atuendo de sus majas- hasta la asimilación profunda de rasgos técnicos del maestro aragonés y de códigos de captación de la personalidad del retratado. Zuloaga participó en numerosas exposiciones parisinas, resultando interesantes las elogiosas comparaciones que la crítica francesa hizo de su pintura con la obra de Goya ${ }^{33}$. Así, el crítico Gustave Geffroy afirmó en 1899 “el Sr. Ignacio Zuloaga, que viene de España, tiene la amargura y la gracia salvaje de Goya”.

La pasión que Zuloaga sintió por la obra de Goya no se limitó a una influencia pictórica. En 1915 compró la casa natal del pintor aragonés en Fuendetodos, dando impulso al edificio de las escuelas municipales anejo a esta vivienda, así como a un monumento conmemorativo ejecutado en 1920 por el escultor Julio Antonio ${ }^{34}$. A estas acciones se sumó la participación en espectáculos en los que se recreaba la obra del maestro, como fueron los decorados para ópera aquí investigados o la organización de corridas goyescas en Zaragoza en 1927 y San Sebastián en 1928. Al igual que sucedió con los tableaux vivants, fueron acontecimientos coordinados por un pintor de primera fila, en los que se planificó minuciosamente la puesta en escena. En la corrida zaragozana, por recomendación de Zuloaga, la Junta del Centenario de Goya dio la instrucción de que los asistentes vistiesen inspirándose en la España de Carlos IV. Tras la corrida, el semanario barcelonés La fiesta brava evocó de manera literaria esa resurrección de los personajes de la época de Goya: "se ven empolvados peluquines, capas de durancillo y vestidos de medio paso; desfilan con don Francisco, Ramón de la Cruz, Jovellanos y Moratín; figuran en el cortejo Meléndez y Quintana, Isidoro Maiquez, la Tirana, Rita Luna...”35. El caso de la corrida donostiarra de 1928 fue similar, contando

32 La influencia que Goya ejerció sobre el pintor vasco fue analizada por la profesora María Jesús Quesad en el marco del congreso Goya, 250 años después: QUESADA MARTÍN, M. J.: "Goya e Ignacio Zuloaga" en VV. AA, Actas del Congreso Goya 250 años después. 1746-1996. Marbella, Museo del grabado español contemporáneo, 1996, pp. 307-316. El profesor Jesús Pedro Lorente profundizó sobre el coleccionismo de goyas por parte de Zuloaga y sobre su "canonización" del pintor aragonés LORENTE LORENTE, J. P. "La pasión por Goya en Zuloaga y su círculo", Artigrama, 25, 2010, pp. 165-183.

33 BOZAL CHAMORRO, L. y JIMÉNEZ BURILLO, P. (comisarios): Zuloaga en el París de la Belle Époque. Madrid, Fundación Mapfre, 2017, pp. 10-25.

34 CASTÁN CHOCARRO, A.: Señas de identidad. Pintura y regionalismo en Aragón (1898-1939). Zaragoza Institución Fernando el Católico, 2016, p. 217.

35 "La corrida goyesca de Zaragoza", La fiesta brava. Barcelona, 19 de mayo de 1927, pp. 3-8. 
Zuloaga en esta ocasión con la colaboración de artistas locales como Mauricio Flores Kaperotxipi, autor de dos grandes pinturas ejecutadas para el ornato de la plaza: un retrato de Goya y una representación de una paleta con la imagen de la maja vestida ${ }^{36}$

El pintor de Éibar era una autoridad en las cuestiones referidas a Goya en la España de comienzos del siglo XX. Así, desde finales del siglo XIX se interesó por la adquisición de obras del pintor de Fuendetodos, llegando a poseer el retrato de la condesa de Baena (1819), el del general Palafox (ca. 1814), una plancha de cobre inédita de Goya o un retrato de Camilo Goya (ca. 1783-1785 $)^{37}$. Esta activa participación en el mercado artístico hizo del pintor un experto goyista, cuyo asesoramiento fue demandado con frecuencia por compradores de arte. Toda esta labor dio a Zuloaga un profundo conocimiento de la obra de Goya, lo que permite comprender la confianza que Enrique Granados depositó en él desde el nacimiento del proyecto de Goyescas.

\section{LAS MAQUETAS DE IGNACIO ZULOAGA PARA GOYESCAS: UN PATRIMONIO ARTÍSTICO Y DOCUMENTAL INÉDITO}

Hubo que esperar hasta diciembre de 1919 para que Goyescas fuese estrenada en París, no sin dificultades. Fallecido Granados, tanto los descendientes del compositor como Fernando Periquet se pusieron en contacto con Jacques Rouché para tramitar las cuestiones relativas al debut de la ópera en la capital francesa. La correspondencia entre todas las partes interesadas revela el enfrentamiento entre los hijos de Granados y Periquet por cuestiones relativas a la autoría de la obra. Así, en septiembre de 1916, Eduardo Granados se ponía en contacto con el director de la Ópera de París para anunciar la ruptura con el libretista ${ }^{38}$

La segunda contrariedad a la que tuvo que hacer frente la Ópera de París fue la desaparición de la orquestación musical. Para tratar de encontrar las partituras originales, Jacques Rouché contactó con los hijos del artista primero y con la Metropolitan Opera House después. La partitura original había sido entregada por el compositor, tal y cómo se ha señalado anteriormente, a la Hispanic Society of America ${ }^{39}$.

36 "La corrida govesca de San Sebastián", La Nación. Madrid, 23 de julio de 1928, p. 9.

37 LAFOND, P.: "La collection de M. Zuloaga", Les Arts, 02, 1908, pp. 22-31

38 ATNO. AJ/12/1205. Carta de Eduardo Granados a Jacques Rouché. Barcelona: 9-06-1916.

39 El Dr. Carrasco Formiguera fue quien indicó al director de la Ópera de París que la partitura origina
Granados había confiado en Zuloaga desde el principio para la première de la ópera en París. Hacia marzo de 1915, según afirmó Granados, Zuloaga ya iba pensando en cantantes españolas para su participación en el proyecto, contando con «La Argentina», Antonia Mercé y Luque ${ }^{40}$, quien para entonces ya había triunfado en la Ópera de París y fue una de las mayores renovadoras de la danza en España ${ }^{41}$. En otra carta enviada por Rouché al maestro Granados, el director parisino afirmó que Zuloaga se encontraba trabajando en los decorados de la ópera en junio de $1915^{42}$.

Fallecido el compositor, el propio Jacques Rouché mantuvo su predilección por Ignacio Zuloaga como diseñador de los decorados de Goyescas, gracias en parte a la intercesión del cuñado del pintor vasco, Maxime Dethomas, director artístico de la Ópera y uno de los creadores más cercanos a Rouché desde que trabajasen juntos en el Théâtre des Arts de París. Por este motivo, Zuloaga permaneció cercano a la producción y avisó de su próximo estreno a Periquet en septiembre de $1919^{43}$. El libretista escribió al director de la Ópera sugiriendo la participación de la bailarina española Amalia Molina. El encargado de contactar con ella fue Ignacio Zuloaga, quien en octubre comunicó a la Palais Garnier las condiciones bajo las que la artista trabajaría, cobrando 250 francos diarios más los viajes de ida y vuelta en primera clase para ella y un acompañante. En ese mismo telegrama, Zuloaga añadió que los accesorios saldrían hacia París al día siguiente, de lo que se deduce que envió a la capital francesa atrezo original procedente de España ${ }^{44}$.

Para el estreno de la ópera fueron editadas unas invitaciones ilustradas a color, en las que se ofrecía una versión de El baile de San Antonio de la Florida (1777) de Goya, eliminando algunos personajes hasta dejar solamente a la pareja de majos y al guitarrista ${ }^{45}$ (fig. 2). Aunque no figura la firma de ningún artista en la ilustración, su estilo recuerda a los diseños de carteles de Maxime Dethomas, por lo que posiblemente fuese el autor de la imagen.

se conservaba en la HSA: ATNO. AJ/12/1205. Carta de R. Carrasco Formiguera a Jacques Rouché. Barcelona: 23-09-1919.

40 ATNO. AJ/12/1205. Carta de Enrique Granados a Jacques Rouché. Barcelona: 10-03-1915.

41 MURGA CASTRO, I.: Escenografía de la danza en la Edad de Plata (1916-1936). Madrid, Consejo Superior de Investigaciones Científicas, 2009, pp. 96 y 97.

42 ATNO. AJ/12/1205. Carta de Jacques Rouché a Enrique Granados. París. 22-06-1915.

43 ATNO. AJ/12/1205. Carta de Fernando Periquet a Jacques Rouché. Santa Cruz de Tenerife: 21-09-1919.

44 ATNO. AJ/12/1205. Telegrama de Ignacio Zuloaga a la Ópera de París. Madrid: 20-10-1919.

45 Bibliothèque Nationale de France. Richelieu-Arts du spectacle. Goyescas, opéra d'Enrique Granados: invitation illustrée. Ref. FRBNF41396619. 


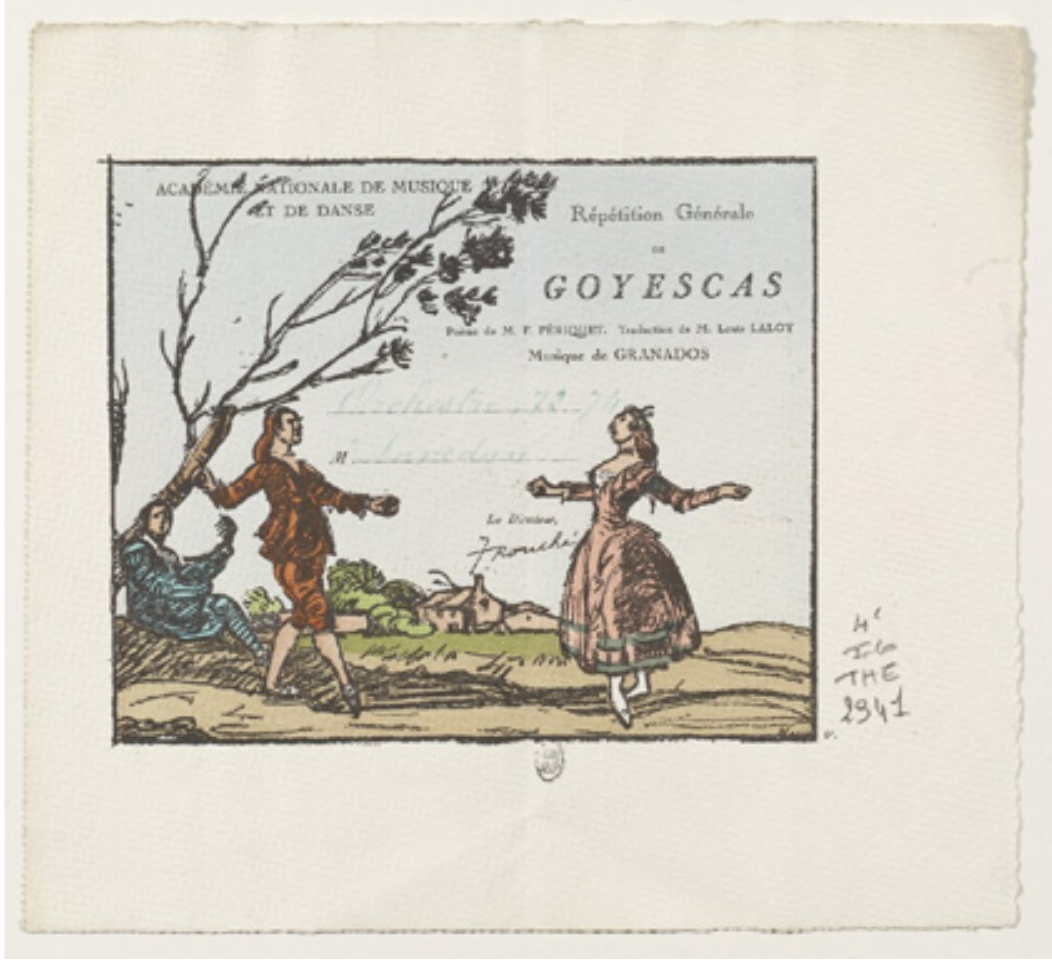

Fig. 2: Invitación ilustrada para Goyescas, Maxime Dethomas, 1919. Bibliothèque Nationale de France, Richelieu - Arts du Spectacle, Paris

En estudios anteriores fueron difundidos los bocetos de los tres cuadros de la ópera. Para el primer cuadro se conserva un logradísimo lienzo en el Evergreen Museum de la John Hopkins University de Baltimore ${ }^{46}$. Los bocetos del segundo y tercer acto se conocían a partir de las imágenes publicadas en 1919 por el diario francés Comoedia ${ }^{47}$.

46 LORENTE LORENTE, J. P.: “La pasión por Goya..., op. cit., p. 170

47 BERNIER, J.: "A l'Opéra. "Goyescas»", Comoedia Illustré. París: 5 de enero de 1920, pp. 122-123. Las fotografías de los bocetos del segundo y tercer acto fueron difundidas en: JUBERÍAS GRACIA, G. “Goyescas (1915) ..., op. cit., pp. 267-269.
A estos bocetos hay que añadir las dos maquetas de decorados del primer y tercer cuadro, conservadas en París en las reservas de la Bibliothèque-Musée de l'Opéra, dependiente de la Bibliothèque Nationale de France, que no han sido difundidas hasta la fecha ${ }^{48}$. Del mismo modo, tampoco se han investigado las fotografías custodiadas por esta misma institución de los decorados del tercer cuadro y de los actores vestidos para la representación de la ópera $^{49}$. Por último, también en las reservas de este museo se conservan cincuenta y siete diseños de trajes para Goyescas, realizados por el equipo de vestuario a partir de originales de Maxime Dethomas ${ }^{50}$

En primer lugar, hay que analizar las maquetas desmontadas ${ }^{51}$. Al igual que hicieron otros artistas, Zuloaga y Dethomas donaron dos de las maquetas tridimensionales de Goyescas a esta institución. Ambas piezas constituyen no solamente dos obras de considerable valor artístico, sino que además poseen un gran interés como documentos para la investigación de la escenografía operística de principios del siglo XX. En ambas se construye un decorado tridimensional a partir del recorte de planos bidimensionales superpuestos, que generarían una imagen volumétrica al ser anclados al suelo del escenario. Los recortes tienen diferentes dimensiones, desde pequeños detalles compositivos como pueden ser árboles, referencias arquitectónicas o personajes; hasta elementos más grandes, tal es el caso de la vista de la ciudad de Madrid desde la pradera de San Isidro en el primer cuadro o el marco vegetal del tercer cuadro.

Conviene comparar la maqueta del primer cuadro con el boceto conservado en Estados Unidos. Recordemos cómo Zuloaga reprodujo en el segundo algunos de los más célebres bocetos y cartones para tapices de Goya. El paisaje urbano madrileño de fondo y la acumulación de personajes procedían de La pradera de San Isidro $(1788)^{52}$. En la maqueta Zuloaga introdujo un paisaje prácticamente igual al utilizado en el boceto, representando

48 Bibliothèque-Musée de l’Opéra [BMO]. Maquette de décor en volume des actes I et II, par Ignacio Zuloaga. Ref. FRBNF42615109 y BMO. Maquette de décor en volume du 3e acte, par Maxime Dethomas. Ref. FRBNF42598384.

49 BMO. Photographies des maquettes de décors del'Opéra avec plans, H. Laffargue. Ref. FRBNF45779301. 50 BMO. Cinquante-sept maquettes de costumes d'après Maxime Dethomas. Ref. FRBNF44240580.

51 Por motivos de conservación preventiva las maquetas se almacenan desmontadas en las reservas de Bibliothèque-Musée de l'Opéra, debido a su fragilidad e inestabilidad, fruto de la aplicación de técnicas como la acuarela sobre cartulina.

52 Se trata de un boceto previo al cartón para tapiz, ideado por Goya para el Palacio Real de El Pardo Museo Nacional del Prado, número de catálogo: P000750 
de manera muy esquemática los elementos más destacados del perfil de la ciudad de Madrid, como la cúpula de la basílica de San Francisco el Grande, igual que hizo Goya. En la maqueta el pintor de Éibar concedió una gran importancia al cielo, que ocupa las tres cuartas partes de la composición. En ello se diferencia del original del maestro aragonés, en el que el cielo ocupa la mitad del lienzo. Además, mientras Goya representó un cielo amarillento y algo polvoriento, Zuloaga lo pintó azul intenso con nubes blancas en forma de torbellino, llevando a cabo una interpretación personal sin caer en la copia.

Por otro lado, aunque El columpio (1779) aparece representado en la maqueta, El quitasol (1777) y El pelele (1791-1792) - que sí figuran en el boceto- no se encuentran en la maqueta. Posiblemente se deba a que estas escenas no formaron parte del decorado, sino que fueron representadas por actores y actrices ataviados a la manera de los cartones goyescos. El columpio, al igual que el pintado por Goya, aparece suspendido de unas ramas de árbol muy delgadas, favoreciendo el efecto de ligereza.

La última diferencia que hemos detectado es que, mientras en el boceto la escena quedaba a cielo abierto, en la maqueta un marco de frondosa vegetación cierra el conjunto por los laterales y la parte superior. Sobresale el magnífico detalle de la ermita de San Antonio de la Florida, recortada sobre un único plano, muy similar a la representada en el boceto (fig. 3). El año de estreno de la ópera en París coincidió con el traslado de los restos de Goya a un sepulcro instalado en su interior ${ }^{53}$. Por su representación de todo un muestrario de majas, chisperos, caballeros embozados y mendigos, las pinturas de Goya en el templo fueron muy apreciadas por los madrileños. Además, su difusión había venido favorecida por la publicación en 1876 de una serie de grabados al aguafuerte copia de estos frescos, ejecutada por José María Galván y Candela ${ }^{54}$.

53 Dicha ermita había sido declarada Monumento Nacional en 1905. Sin embargo, su uso litúrgico estaba poniendo en peligro la conservación de las pinturas de Goya. En la segunda década del siglo XX hubo voces que reclamaron la interrupción del culto en la ermita. Así lo reclamaba Pedro de Répide, reclamando la musealización del monumento como un símbolo del Madrid del siglo XVIII: "Lo que Goya pintó al fresco en San Antonio de la Florida, está convirtiéndose en bocetos al humo, si no se remedia con tiempo y buena voluntad (...). Una vez se trató de la adquisición de la casa de Lope de Vega por Ayuntamiento para establecer allí un museo madrileño del siglo XVII Y San Antonio de la Florida deb TVII". DE RÉPIDE GAILEOOS, P. "Mach Antonio de la Flon da debe Esfera. Madrid, 6 de mayo de 1916, p. 11

54 VV. AA.: El grabador al aguafuerte. Colección de obras originales y copias de las selectas de autores españoles, vol. 3. Madrid, Sociedad de Artistas, 1876

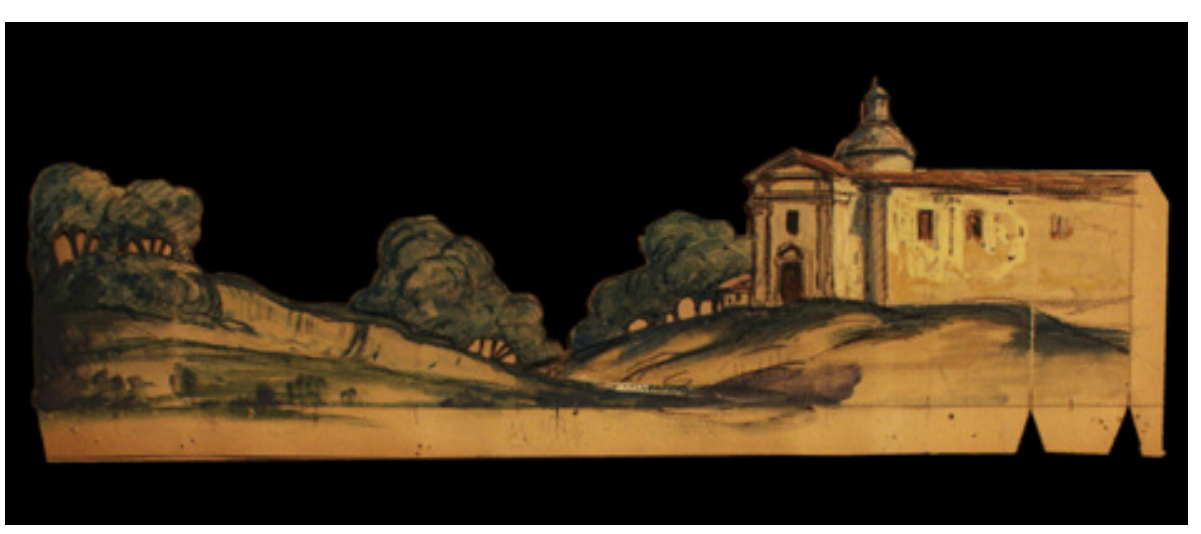

3: Detalle de la maqueta del primer cuadro de Goyescas (ermita de San Antonio de la Florida), Ignacio Zuloaga, 1919. Bibliothèque-Musée de l'Opéra, Bibliothèque Nationale de France, París

Por desgracia, la maqueta del segundo cuadro - en el que se representaba el interior de un patio español - no se ha conservado. Tan sólo podemos imaginar cómo fue a partir de la fotografía del boceto publicada en Comoedia $a^{55}$. Para este tercer cuadro, Zuloaga había pedido ayuda a su tío Daniel en $1916^{56}$

Para el $2^{\circ}$ acto me hacen falta algunos datos de patios y cuadros. La escena es un baile de candil en tiempos de Goya, así es que te ruego encargues a cualquier fotógrafo de Segovia que me haga el patio de la casa donde tú vives y el de la casa donde viviste antes, hacia la Canongía y las posadas que nos gustan tanto y que están en la calle que va del Azoguejo a la estación, pasando por la Academia y algunos otros patios o cuadras que yo no recuerdo (...)

El resultado fue el de un patio oscuro, inmerso en una ambientación nocturna, tal y como apunta el libreto de la ópera. Zuloaga se alejó del casticismo del patio diseñado por Rovescalli para el estreno en Nueva York y de los decorados andalucistas de Carmen en 1875.

55 JUBERÍAS GRACIA, G.: “Goyescas (1915) ...”, op. cit., p. 267

56 GÓMEZ DE CASO ESTRADA, M.: Correspondencia de Ignacio Zuloaga con su tío Daniel. Segovia, Diputación Provincial de Segovia, 2002, p. 522. 
La maqueta del tercer cuadro, diseñada por Maxime Dethomas (fig. 4), puede ser comparada con la imagen del boceto publicado en Comoedia. Al igual que sucede con el primer cuadro existe una gran correspondencia entre ambas piezas. En este caso los colores utilizados son más fríos, oscuros y apagados, contribuyendo a la atmósfera trágica que envuelve al final de la ópera. El fondo urbano, inspirado en la arquitectura española del siglo XVI se mantuvo intacto. También la arboleda que enmarca la escena. En ambos casos, una verja separa la calle del jardín del palacio de Rosario y en la maqueta Dethomas añadió una fuente.

Los modelos arquitectónicos utilizados por Dethomas para ambientar este cuadro no fueron elegidos al azar. El estilo evocado tanto en el boceto como en la maqueta es el renacentista español, elección que podemos relacionar con el renovado interés por la arquitectura plateresca o protorrenacentista a partir del pabellón español para la Exposición Universal de París de 1900. Su arquitecto, José de Urioste y Velada, escogió modelos de finales del siglo XV y comienzos del siglo XVI como el salmantino Palacio de Monterrey, con el propósito de transmitir una imagen de España inspirada en una época de esplendor, la de los Reyes Católicos y Carlos V, queriendo dejar atrás el perfil neoislámico que hasta entonces había caracterizado a España en su imagen internacional ${ }^{57}$. En este caso en concreto, hemos podido localizar el conjunto arquitectónico copiado en la maqueta. Se trata del exterior de la Capilla Real de la catedral de Granada, lugar escogido por los Reyes Católicos para su sepultura, un símbolo precisamente de esa etapa de expansión territorial, convertida en un referente histórico y cultural en un momento en el que el país arrastraba la crisis del 98 y la pérdida de las últimas colonias. El palacete representado corresponde a la Lonja de mercaderes, un edificio adosado a la Capilla Real, construido por Juan García de Pradas entre 1518 y 1522 siguiendo los diseños de Enrique Egas ${ }^{58}$. El conjunto fue difundido y apreciado por historiadores de la arquitectura que trabajaron en los mismos años en que Zuloaga y Dethomas se encontraban realizando los decorados de Goyescas (fig. 5) (9. $^{59}$

57 ÁlVAREZ RODRÍGUEZ, M. V.: El pensamiento arquitectónico en España en el siglo XIX a través de la revistas artísticas del reinado isabelino. Salamanca, Ediciones Universidad de Salamanca, 2015, p. 1358.

58 PÉREZ RUÍZ DE LA FUENTE, M. D.: Temas y elementos ornamentales en el arte de Granada desde el Renacimiento hasta el Manierismo. Granada, Universidad de Granada, 2001, p. 44

59 Dicho edificio llamó la atención del matrimonio de historiadores del arte americanos Arthur Byne Mildred Stapley, connervadores de la Hispanic Society of America para la que publicaron sur obra SpaMish Archtect of nish Achitetyre of the Sixteenth Centurys general wew of the Pleresque and Horta styles, en 1917 incluyendo varias fotografias del conjunto grandino. STAPLEY, M., Y BYNE, A... Spanish Architecture of the Sixteenth Century; general view of the Plateresque and Herrera styles. Nueva York, Hispanic Society of America, 1917, pp. 293-294.

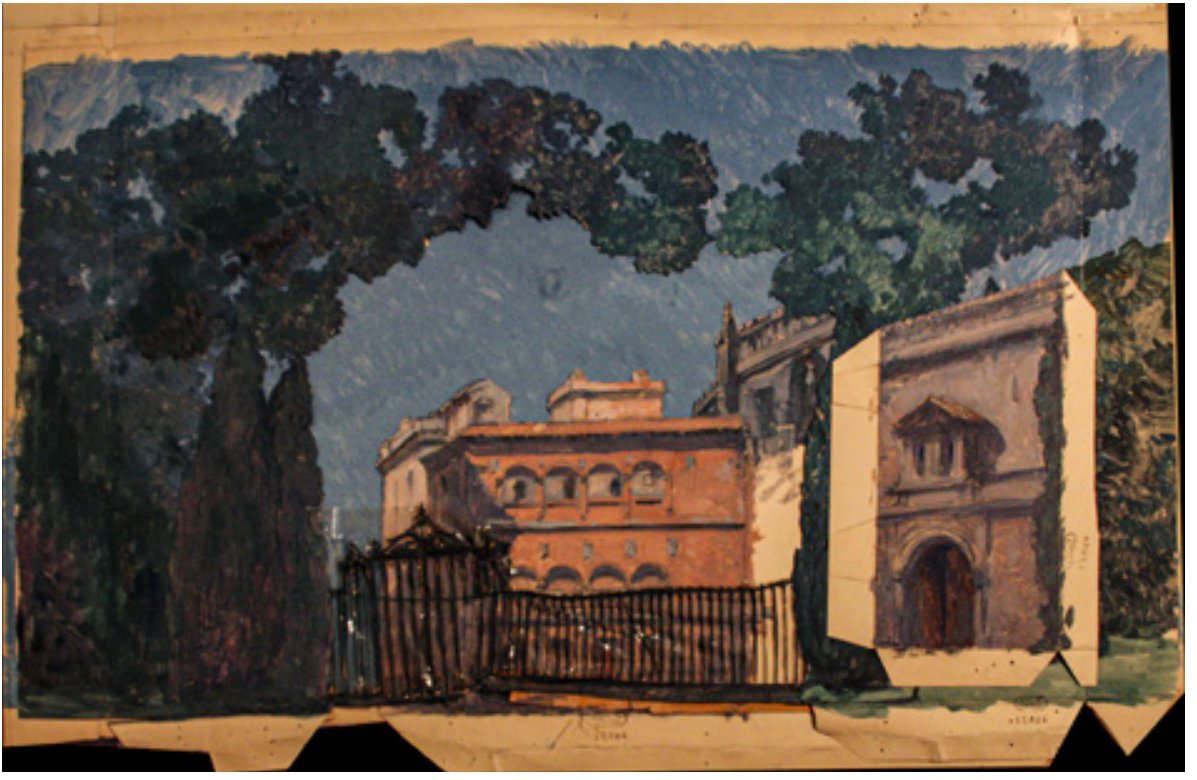

ify 4: Maqueta desmontada para el tercer cuadro de Goyescas, Maxime Dethomas, 1919. Bibliothèque-Musée de l'Opéra, Bibliothèque Nationale de France, París

La elección de este tipo de arquitectura demuestra el deseo de renovación presente en la puesta en escena de Goyescas, testimonio del debate sobre la identidad española. Además, el artista vasco debía de conocer bien la Capilla Real, pues años después copió un detalle del banco del retablo mayor y lo utilizó para una escenografía de El retablo del Maese Pedro de Manuel de Falla, estrenada en $1923^{60}$

Por otro lado, al igual que en el primer cuadro, eliminó la referencia del boceto al Entierro de la sardina (1812-1819), que en el boceto puede adivinarse más allá de la verja y la imagen de Rosario desplomada sobre el cuerpo de Fernando, apelando a Dios.

60 VALLEJO PRIETO, J.: “Un acercamiento a El retablo de Maese Pedro de Falla y Zuloaga”, en PÉREZ-FA JARDO, C. A. (coord.): Ignacio Zuloaga, Manuel de Falla. Historia de una amistad. Madrid, Centrocentro Cibeles, 2015, p. 159 


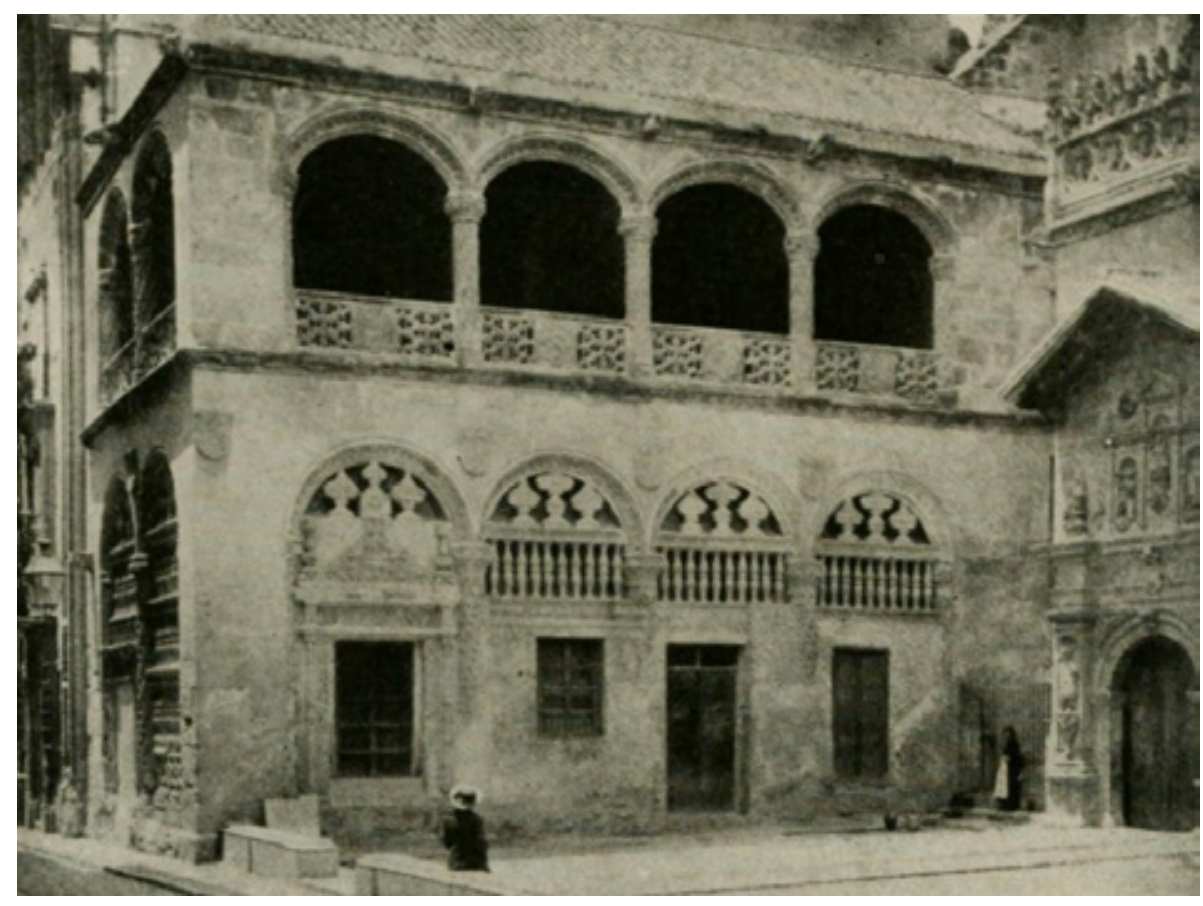

Fig. 5: Lonja de Mercaderes y acceso a la Capilla Real de Granada, 1917. STAPLEY, M., y BYNE, A.: Spanish Architecture of the Sixteenth Century... op. cit.

Además, la Ópera de París fotografiaba las maquetas montadas de los espectáculos más importantes que en ella se estrenaban. Para Goyescas, H. Laffargue fotografió la correspondiente al tercer cuadro (fig. 6), permitiéndonos conocer su aspecto montada ${ }^{61}$.

A estas imágenes habría que sumar los retratos fotográficos de cantantes ataviados con el vestuario de Goyescas. Es el caso de M. Laffitte interpretando a Fernando, de la soprano Marthe Chenal o de la contralto Ketty Lapeyrette vestida de maja con mantilla, peineta y abanico (fig. 7). Todos ellos son documentos que permiten apreciar el resultado final del trabajo de diseño llevado a cabo por Zuloaga y Dethomas.

61 BMO. Photographies des maquettes de décors de l'Opéra. Ref. FRBNF45779301.

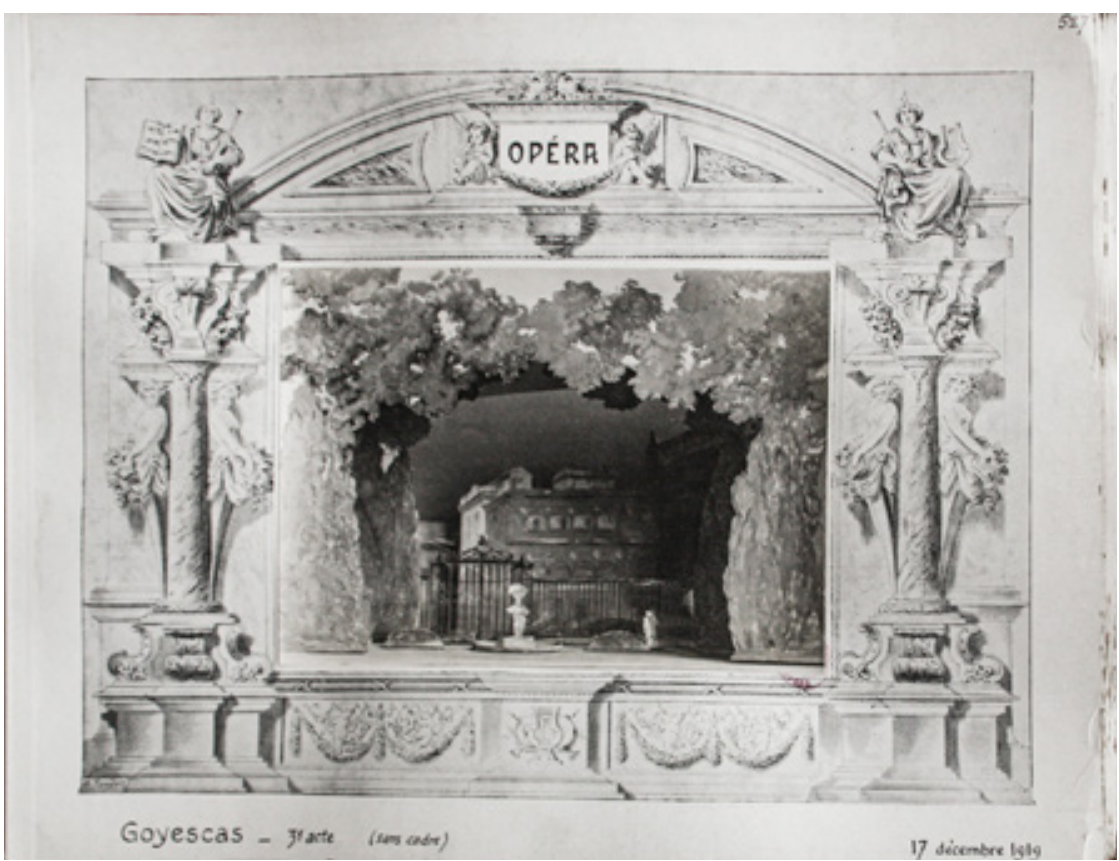

Fig. 6: Fotografía de la maqueta montada del tercer cuadro de Goyescas, H. Laffargue, 1919. Bibliothèque-Musée de l'Opéra, Bibliothèque Nationale de France, París

Este valioso patrimonio se completa con los diseños de vestuario conservados en la Bibliothèque-Musée de l'Opéra. Se trata de 57 diseños elaborados a la acuarela y al gouache, ejecutados por el taller de vestuario de la Ópera, a partir de modelos de Maxime Dethomas (figs. 8 y 9). A estos dibujos se suman seis hojas en las que se reproducen apuntes de telas para las prendas utilizadas en la ópera (fig. 10). En general, lo que se deduce de estos diseños es el conocimiento profundo del vestuario español de época de Goya, gracias al estudio que el propio Zuloaga hizo de los cartones para tapices, tal y como reveló el pintor en su correspondencia. Sin embargo, no todos los elementos del atrezo de Goyescas podían conseguirse en París y en noviembre de 1919 Zuloaga hizo el siguiente encargo a su tío ${ }^{62}$ :

62 GÓMEZ DE CASO ESTRADA, M.: Correspondencia de Ignacio Zuloaga..., op. cit., p. 606. 


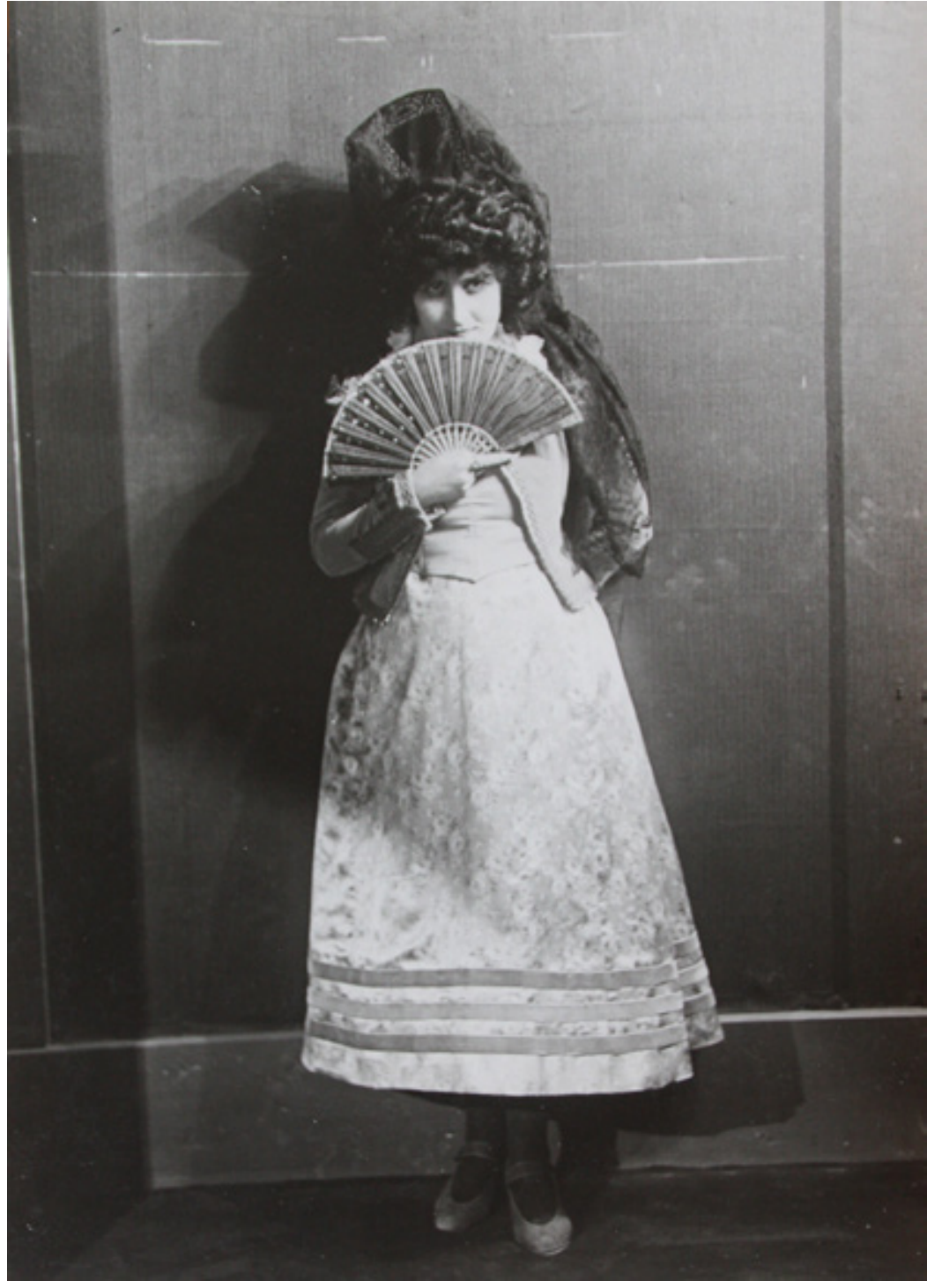

Fig. 7: Ketty Lapeyrette vestida con atuendo de maja, 1919. Bibliothèque-Musée de lOOpéra, Bibliothèque Nationale de France, París
15 peinetas grandes de teja; (tiempos de Goya) [sic.]. Muy altas para poder colocar la mantilla. Esto lo encontrarás en la calle Carretas. Y una docena de tenedores y cucharas de madera y además una docena de roscas de pan como las que hacen en Sevilla; también las hacen los panaderos de ésa. Son las mismas que se encuentran en los tapices de Goya. Todo esto por gran velocidad al señor Lapeyre, Hendaya.

Por lo tanto, de estos encargos y del detallismo con que fueron elaboradas las telas del vestuario, se deduce el interés de Dethomas y Zuloaga en la reproducción veraz de elementos de la España de finales del siglo XVIII.

El éxito de Goyescas en París fue rotundo y a ello contribuyeron en buena medida los decorados de Zuloaga y Dethomas. El pintor vasco escribió a varios de sus amigos contándoles su gran triunfo, entre ellos al escritor argentino Enrique Larreta, al que le expresó ${ }^{63}$ :

Hace unos días se estrenó en la Ópera de París "Goyescas" del pobre Granados. Yo hice las decoraciones de los dos primeros actos, y debo decirle (aunque es tonto y pretencioso de parte mía) que he obtenido un triunfo tremendo. En el segundo acto, al levantarse el telón (representaba un baile de candil en un patio de posada) se levantó todo el público a aplaudir y gritando de entusiasmo.

Por último, aportamos en este estudio algunos datos acerca de la recepción de los decorados de Goyescas en los escenarios parisinos. Numerosos periódicos y revistas se hicieron eco del trabajo de Zuloaga y Dethomas en esta obra. En palabras del crítico de arte René-Jean en el diario Comoedia ${ }^{64}$

Por el talento del Sr. Zuloaga, los dos primeros cuadros; por el del Sr. Maxime Dethomas, el último, la decoración y tus trajes de los Goyescas han evocado perfectamente ante nuestros ojos la España de Goya; la famosa maja misma ha bajado de su marco para vivir ante nosotros, encarnada por la señorita Chenal.

63 GÓMEZ DE CASO ESTRADA, M.: Falla, Larreta y Zuloaga, ante "La gloria de don Ramiro". Pedraza, Museo Ignacio Zuloaga. Castillo de Pedraza, 2006, p. 55

64 JEAN, R.: "La mise en escène et les décors. Goyescas". Comedia, París, 18 de diciembre de 1919, p. 2. 


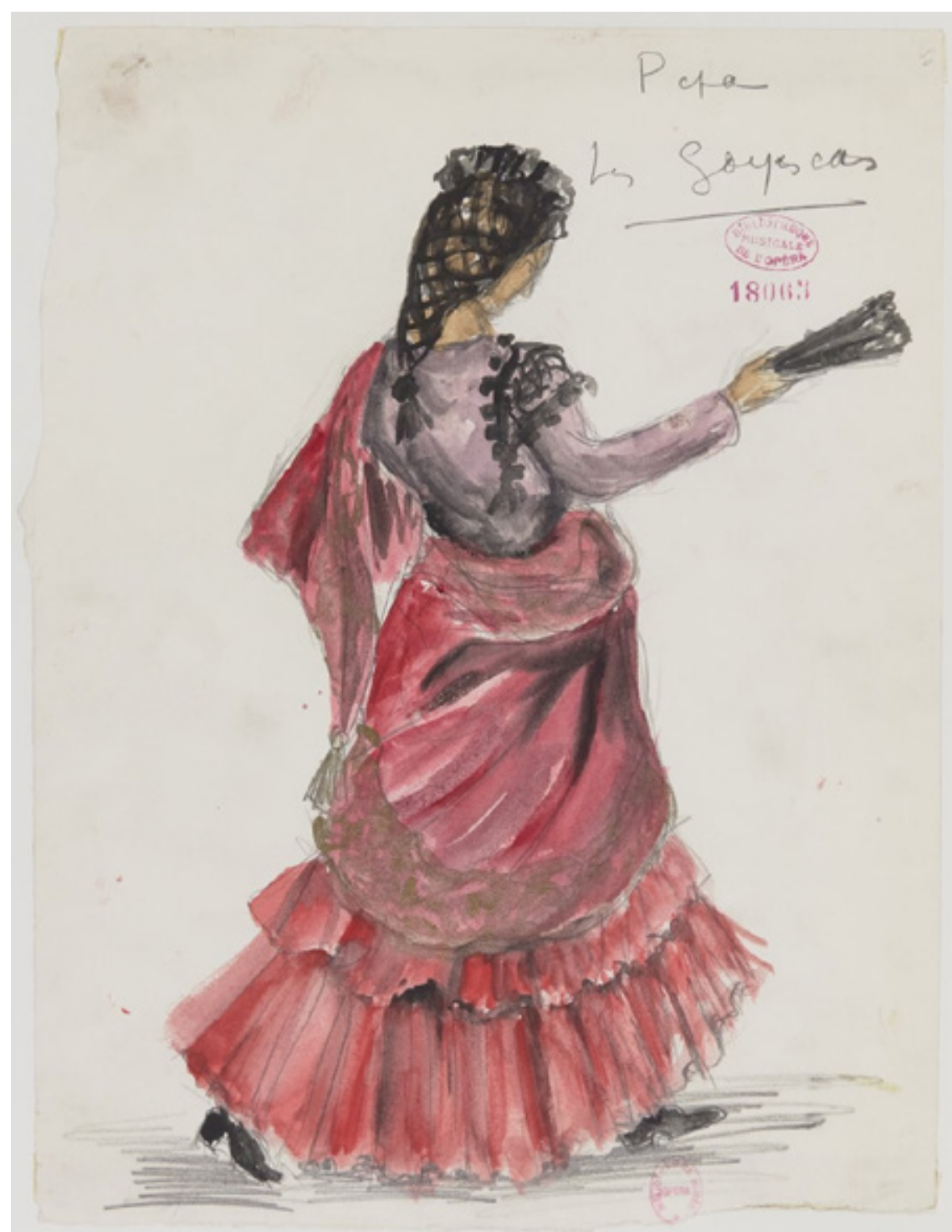

Fig. 8: Pepa, figurín para Goyescas. Diseños de vestuario según M. Dethomas, 1919. Bibliothèque-Musée de l'Opéra, Bibliothèque Nationale de France, París

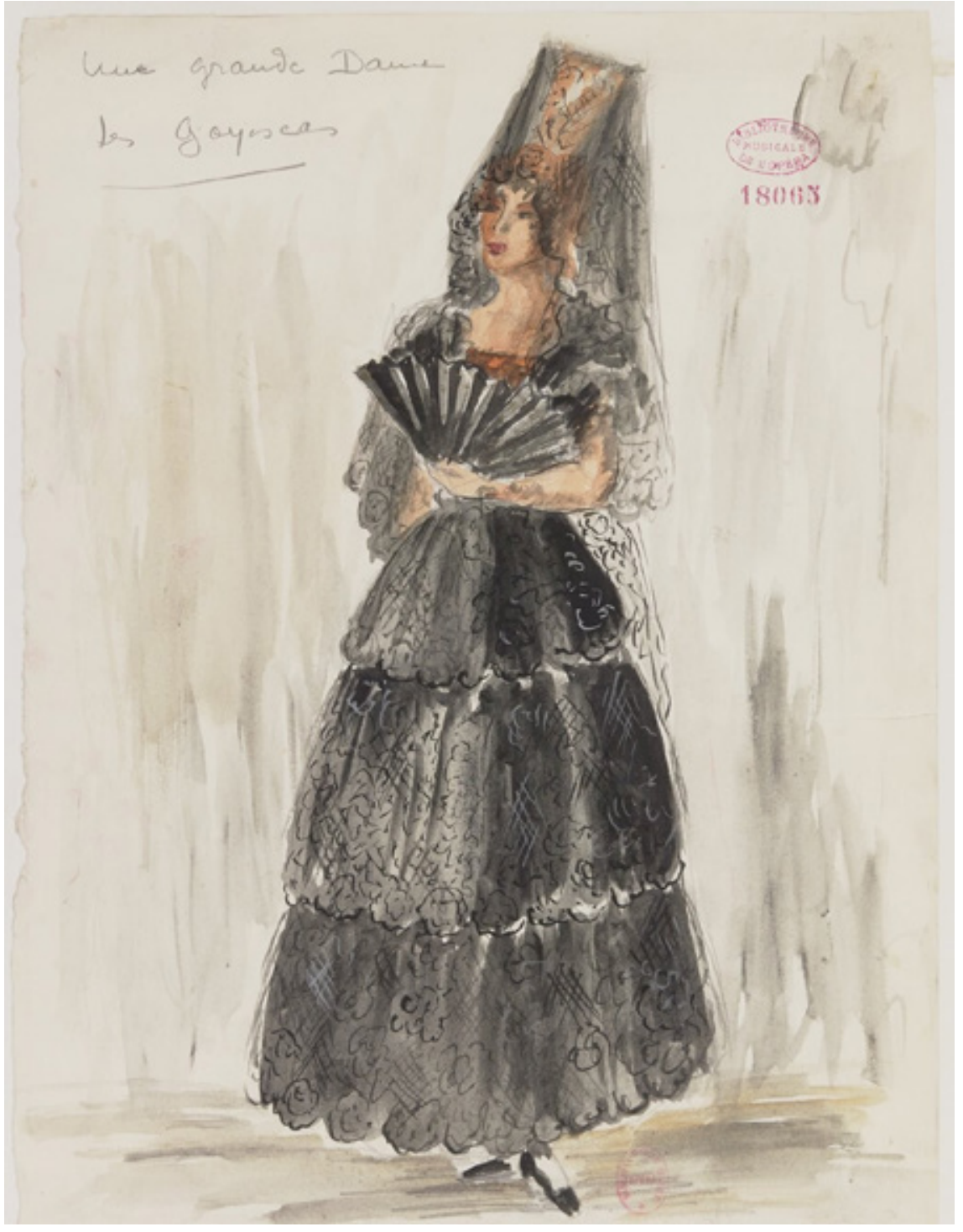

Fig. 9: Une grande dame, figurín para Goyescas. Diseños de vestuario según M. Dethomas, 1919. Bibliothèque-Musée de l'Opéra, Bibliothèque Nationale de France, París 


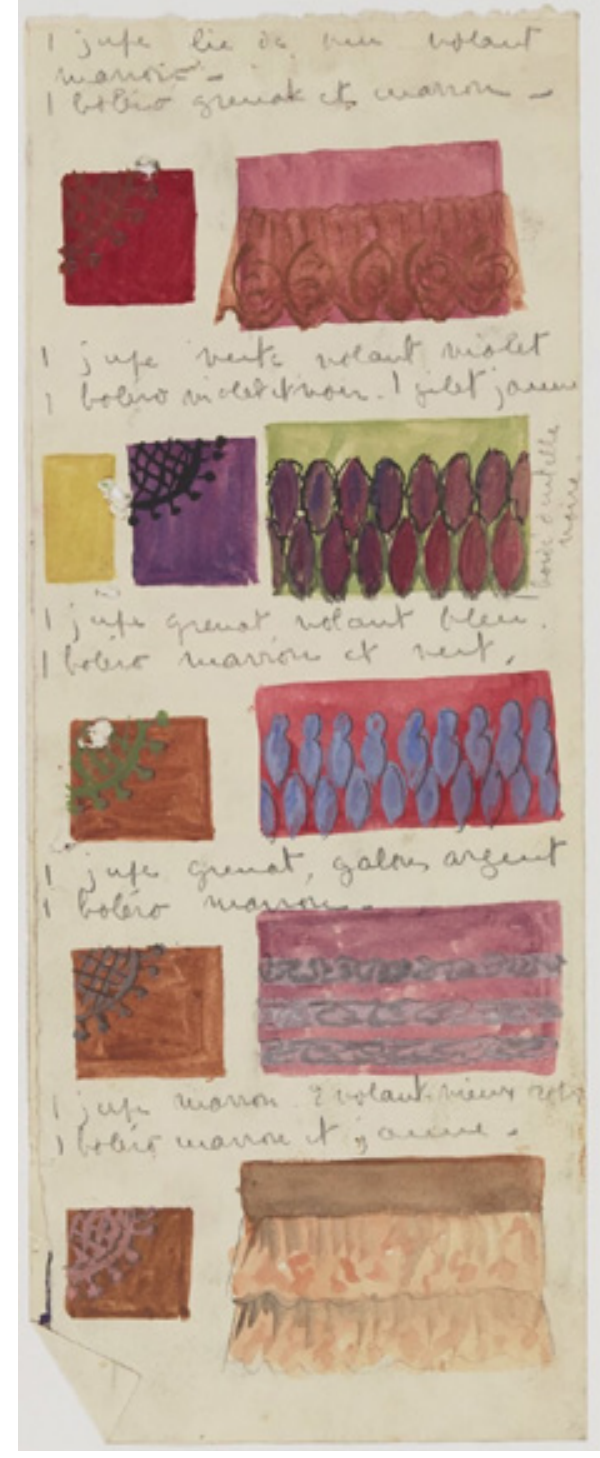

Fig. 10: Modelos de telas para el vestuario de Goyescas. Diseños según Maxime Dethomas, 1919. Bibliothèque-Musée de l'Opéra, Bibliothèque Nationale de France, París
A lo largo de su reseña describió minuciosamente la puesta en escena de la ópera, cuadro por cuadro, destacando la fuerza y la sobriedad del decorado del tercero, el diseñado por Dethomas. Concluyó afirmando:

Aunque los tres decorados de Goyescas son obra de dos artistas diferentes, se reúnen en una misma unidad, en un mismo acorde de líneas y colores, para subrayar la música y celebrar al gran pintor español que prestó su nombre a estos nuevos Caprichos.

Este rasgo apuntado por René-Jean se comprueba a la perfección al apreciar los bocetos, las maquetas originales y la fotografía de la tercera maqueta montada. Son tres escenografías elaboradas al unísono, para las que Zuloaga aplicó su bagaje y conocimiento del arte español, al que Dethomas sumó su buen hacer y experiencia en el ámbito del diseño teatral.

También la prensa española publicó noticias sobre el estreno de Goyescas en París, haciendo alusión a los decorados de Zuloaga y Dethomas. El escritor novecentista Alberto Insúa los describía de la siguiente manera en La Correspondencia de España ${ }^{65}$ :

En el escenario van cobrando vida los tapices de Goya... He aquí el Pelele... Ya llega la carroza... Y ahora la silla de manos... Las decoraciones, según los bocetos de Zuloaga Dethomas — los dos de Zuloaga sobre todo_- sorprendentes de españolismo... Los trajes de las majas y los chisperos, irreprochables. Todo sabe a Goya en el escenario

No podemos concluir este estudio sin aludir al seguimiento que tanto la prensa francesa como la española hizo del trabajo de la bailarina Amalia Molina, responsable de dar vida a los diseños de Zuloaga y Dethomas junto al resto del elenco. Su éxito fue aprovechado por Mariano de Cavia para reclamar al Ministro de Instrucción Pública y Bellas Artes la creación de una cátedra de Crotalogía en el Real Conservatorio de Música y Declamación ${ }^{66}$. La calidad de su trabajo llevó a Mariano de Cavia a afirmar: “¡Oh queridísima España! ‘Todavía no te has muerto!’”

El éxito de Goyescas y de sus decorados no se constata solamente en su repercusión en prensa. Un mes después de la puesta en escena en la Ópera de París, Zuloaga y Amalia de Molina aprovecharon la popularidad de su espectáculo para crear un número musical

65 INSÚA Y ESCOBAR, A.: "Notas de París. Estreno de Goyescas". La Correspondencia de España, Madrid, 21 de diciembre de 1919, p. 1

66 DE CAVIA Y LAC, M.: "La patria y la crotalogía”. El Sol, Madrid, 26 de diciembre de 2019, p. 1. 
en el Teatro Olympia de la capital francesa. La cantante interpretó canciones y danzas tradicionales españolas con versiones de cuadros de Goya y pinturas de Zuloaga como fondo de escena ${ }^{67}$. Los vestidos de Amalia de Molina fueron reproducciones de los existentes en la pintura de Goya y Zuloaga creó un cuadro distinto para cada canción interpretada por la artista ${ }^{68}$. Aunque no se han conservado imágenes que documenten este espectáculo, algunos de los decorados podrían haber sido reutilizados de Goyescas. Además, la cercanía en el tiempo de ambos espectáculos es otro indicativo del alcance que esta ópera, así como sus intérpretes y diseñadores tuvieron en París, contribuyendo a la difusión de la cultura artística española en su Edad de Plata.

\section{A MODO DE CONCLUSIÓN}

Goyescas, en sus respectivos estrenos neoyorquino y parisino, desempeñó un papel relevante en la divulgación y el conocimiento de la música española y del arte de Francisco de Goya en las dos ciudades más cosmopolitas del mundo en la segunda década del siglo $\mathrm{XX}$. Sin embargo, ambos estrenos ofrecieron dos lecturas muy distintas de lo goyesco y, por ende, de lo español. A lo largo del presente artículo se ha puesto de manifiesto la erudición de Ignacio Zuloaga, de Maxime Dethomas y del propio Granados, intelectuales apasionados por la obra del pintor de Fuendetodos. Esta cultura artística es la que permite comprender la calidad y la novedad de los decorados de Goyescas en su estreno parisino, un conjunto que no ha recibido suficiente atención por parte de la historiografía artística. El análisis de la documentación perteneciente a los Archives du Théâtre National de l'Opéra y el estudio de las maquetas y material fotográfico conservado en la Bibliothèque-Musée de l'Opéra han permitido trazar una visión general de esos decorados, contribuyendo a su valorización.

67 "Espectacles \& Concerts". Figaro: journal non politique, París, 6 de febrero de 1920, p. 3.

68 "Echos \& Informations". Comoedia, París, 2 de febrero de 1920, p. 3. 


\section{BIBLIOGRAFÍA}

ÁLVAREZ RODRÍGUEZ, M. V.: El pensamiento arquitectónico en España en el siglo XIX a través de las revistas artísticas del reinado isabelino. Salamanca, Ediciones Universidad de Salamanca, 2015.

ANDRE-DECONCHAT, S.: "Loeuvre de Goya dans les collections de Jacques Doucet", en VV. AA., Goya graveur. París, Petit Palais, 2008, pp. 161-169.

BAKER, E.: "The Scene Designs for the First Performances of Bizet's Carmen”, 19th Century Music, vol. 13, n 3, 1990, pp. 230-242.

BERGADÀ ARMENGOL, M.: "Añoranza y proyección musical de España en el París de finales del siglo XIX", Cuadernos de música iberoamericana, vol. 5, 2003, pp. 31-32.

BERGADÀ ARMENGOL, M.: "Musiciens espagnols à Paris entre 1820 et 1868", en JAM BOU, L. (coord.), La musique entre France et Espagne. Interactions stylistiques 1870-1939. París, Presses de l'Université de Paris-Sorbonne, 1998, pp. 109-128.

BERNIER, J.: "A l'Opéra. «Goyescas»", Comoedia Illustré. París: 5 de enero de 1920, pp. $122-123$

BOZAL CHAMORRO, L. y JIMÉNEZ BURILLO, P. (comisarios): Zuloaga en el París de la Belle Époque. Madrid, Fundación Mapfre, 2017.

CALVO SERRALLER, F.: La invención del arte español. Barcelona, Galaxia Gutemberg, 2013

CALVOCORESSI, M. D.: "Aux concerts", Comodia Illustré: journal artistique bi-mensuel. París, 15 de abril de 1911, p. 449.

CALVOCORESSI, M. D.: "Aux concerts", Comodia Illustré: journal artistique bi-mensuel. París, 1 de agosto de 1911, p. 681

CASTÁN CHOCARRO, A.: Señas de identidad. Pintura y regionalismo en Aragón (1898 1939). Zaragoza, Institución Fernando el Católico, 2016.
CLARK, W. A.: Enrique Granados: Poet of the Piano. Nueva York, Oxford University Press, 2006.

DE CAVIA Y LAC, M.: “La patria y la crotalogía”. El Sol, Madrid, 26 de diciembre de 2019, p. 1.

DE RÉPIDE GALLEGOS, P.: "Machacando en hierro frío", La Esfera. Madrid, 6 de mayo de 1916, p. 11

GÓMEZ DE CASO ESTRADA, M.: Correspondencia de Ignacio Zuloaga con su tío Daniel. Segovia, Diputación Provincial de Segovia, 2002

GÓMEZ DE CASO ESTRADA, M.: Falla, Larreta y Zuloaga, ante "La gloria de don Ramiro". Pedraza, Museo Ignacio Zuloaga. Castillo de Pedraza, 2006.

INSÚA Y ESCOBAR, A.: "Notas de París. Estreno de Goyescas". La Correspondencia de España, Madrid, 21 de diciembre de 1919, p. 1

J.G.A: “Madrid”, El Día, Madrid, 24 de febrero de 1884, p. 4.

JEAN, R.: "La mise en escène et les décors. Goyescas". Comedia, París, 18 de diciembre de 1919 , p. 2.

JUBERÍAS GRACIA, G., "Ideología y poder en los discursos museográficos: la creación de «salas de Goya» en los museos españoles (1875-1915)”, Potestas, 14, 2019, pp. 143-163.

JUBERÍAS GRACIA, G.: “Goyescas (1915): pintores y escenógrafos al servicio de la ópera de Granados", en CALVO RUATA, J. I.: Goya en la Literatura, la Música y las Creaciones Audiovisuales. Zaragoza, Institución Fernando el Católico, p. 257-261.

LAFOND, P.: “La collection de M. Zuloaga”, Les Arts, 02, 1908, pp. 22-31.

LORENTE LORENTE, J. P.: “De Goya a Zuloaga: Pinturas de los artistas decimonónicos españoles en los museos de Francia”, en CABAÑAS BRAVO, M. (coord.): El arte español fuera de España. Madrid, CSIC, Instituto de Historia, 2003, pp. 331-342. 
LORENTE LORENTE, J. P.: “La pasión por Goya en Zuloaga y su círculo", Artigrama, 25 2010, pp. 165-183.

MURGA CASTRO, I., "Música y pintura encarnadas: las bailarinas de Falla y de Zuloaga", en PÉREZ-FAJARDO, C. A. (coord.): Ignacio Zuloaga, Manuel de Falla. Historia de una amistad. Madrid, Centrocentro Cibeles, 2015, pp. 91-119.

MURGA CASTRO, I.: Escenografía de la danza en la Edad de Plata (1916-1936). Madrid, Consejo Superior de Investigaciones Científicas, 2009.

PÉREZ RUÍZ DE LA FUENTE, M. D.: Temas y elementos ornamentales en el arte de Granada desde el Renacimiento hasta el Manierismo. Granada, Universidad de Granada, 2001

PORTÚS PÉREZ, J.: El concepto de pintura española. Madrid, Verbum, 2012.

QUESADA MARTÍN, M. J.: “Goya e Ignacio Zuloaga”, en VV. AA, Actas del Congreso Goya 250 años después. 1746-1996. Marbella, Museo del grabado español contemporáneo, 1996, pp. 307-316.

REYERO HERMOSILLA, C.: "Soy de España. El casticismo de los pintores españoles en el Salon de París durante el II Imperio”, Cuadernos de Arte i Iconografía, vol. IV, nº 8, 1991, pp. 314-322.

RHODES DRAAYER, S.: Art Song Composers of Spain: An Encyclopedia. Lanham, Scarecrow Press, 2009.

SAZATORNIL RUIZ, L. Y LASHERAS PEÑA, A. B.: "París y la españolada. Casticismo y estereotipos nacionales en las exposiciones universales (1855-1900)", Mélanges de la Casa de Velázquez, n 35-2, 2005, pp. 265-290.

STAPLEY, M., y BYNE, A.: Spanish Architecture of the Sixteenth Century; general view of the Plateresque and Herrera styles. Nueva York, Hispanic Society of America, 1917.

TRANCART, V.: "Denuncia de la españolada", en TRANCART, V.: Visiones desafinadas. Prácticas y representaciones de la guitarra en Madrid y en Andalucía (1883-1922). Zaragoza, Prensas de la Universidad de Zaragoza, 2019, pp. 365-367.
VALLEJO PRIETO, J.: "Un acercamiento a El retablo de Maese Pedro de Falla y Zuloaga", en PÉREZ-FAJARDO, C. A. (coord.): Ignacio Zuloaga, Manuel de Falla. Historia de una amistad. Madrid, Centrocentro Cibeles, 2015, p. 159.

VEGA GONZÁLEZ, J. (ed.): Goya 1900. Catálogo ilustrado y estudio de la exposición en el Ministerio de Instrucción Pública y Bellas Artes. Madrid, Ministerio de Cultura, 2002.

VEGA GONZÁLEZ, J. y VIDAL RIVAS, J.: "El devenir de la Historia del Arte, sus prácticas y sus consecuencias: el caso de Francisco de Goya”, en ARCINIEGA GARCÍA, L.: Memoria y significado: uso y recepción de los vestigios del pasado. Valencia, Universitat de València, 2013, pp. 341-422

VILA, M. C.: Rêve d'Espagne. Musique espagnole en Frace. París, Fayard, 2018.

VV. AA.: El grabador al aguafuerte. Colección de obras originales y copias de las selectas de autores españoles, vol. 3. Madrid, Sociedad de Artistas, 1876

"Echos \& Informations". Comoedia, París, 2 de febrero de 1920, p. 3.

"Espectacles \& Concerts". Figaro: journal non politique, París, 6 de febrero de 1920, p. 3.

“La corrida goyesca de San Sebastián”, La Nación. Madrid, 23 de julio de 1928, p. 9.

“La corrida goyesca de Zaragoza”, La fiesta brava. Barcelona, 19 de mayo de 1927, pp. 3-8.

"Las fiestas del Carnaval. Baile goyesco", La Correspondencia de España, Madrid, 12 de enero de 1910, p. 5 